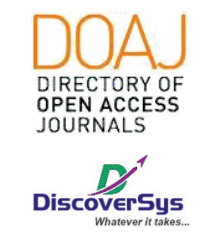

Published by DiscoverSys

\section{Pola pasien anemia yang berkunjung ke Poliklinik Hematologi RSUP Sanglah dari April 2015-April 2017}

\author{
Ni Made Ayu Sintya $D,{ }^{1 *}$ I Wayan Losen Adnyana, ${ }^{2}$ IGP Suka Aryana ${ }^{3}$
}

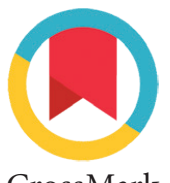

CrossMark

\title{
ABSTRACT
}

Introduction: Anemia is a clinical condition associated with many causes. Anemia is not a disease, it is a syndrome and generally described as a decreased of red blood cell mass and hemoglobin below the normal level. Based on WHO's criteria, someone can be diagnosed with anemia if their hemoglobin level falls below $130 \mathrm{~g} / \mathrm{L}$ for men and below $120 \mathrm{~g} / \mathrm{L}$ for women. Based on a survey made by WHO, about one from every four people in the world suffered from anemia.

Aim: The study aims to evaluate the patient arrival pattern to the Hematological Policlinic in RSUP Sanglah Denpasar.

Method: This is analytic observational research of the anemic patient who came to the Hematological Policlinic in Sanglah General Hospital from April 2015-April 2017.
Result: The highest proportion of anemic patient who came to Hematologic Policlinic in Sanglah General Hospital based on age classification are the age group of 15-59 while based on sexes the percentage of the anemic male patient is $44.2 \%$, and the anemic female is $55.8 \%$ while $2.9 \%$ of that female is currently pregnant.

Conclusion: From the causative point of view, the anemic patient in Hematologic Policlinic in Sanglah General Hospital from April 2015 to April 2017 mostly diagnosed with unspecified type while $58.7 \%$ of the anemic patient come without another health issues and the other $41.3 \%$ have had underlying or accompanying diseases.

Keywords: Anemia, pattern, hematological policlinic

Cite This Article: Sintya, D.N.M.A., Adnyana, I.W.L., Aryana, I.G.P.S. 2020. Pola pasien anemia yang berkunjung ke Poliklinik Hematologi RSUP Sanglah dari April 2015-April 2017. Intisari Sains Medis 11(2): 851-855. D0I: 10.15562/ism.v11i2.207

\section{ABSTRAK}

Pendahuluan: Anemia merupakan suatu kondisi klinis yang diasosiasikan dengan banyak penyebab. Anemia bukan merupakan suatu penyakit melainkan suatu syndrome dan pada umumnya didefinisikan sebagai penurunan sel darah merah dan hemoglobin di bawah nilai normal. Berdasarkan kriteria WHO, seseorang dapat didiagnosis Anemia jika hemoglobinnya berada di bawah $130 \mathrm{~g} / \mathrm{L}$ untuk laki-laki dan di bawah $120 \mathrm{~g} / \mathrm{L}$ untuk perempuan. Berdasarkan survey yang dibuat oleh WHO, anemia diderita oleh satu dari empat orang di dunia.

Tujuan: Penelitian ini bertujuan untuk mengetahui pola kunjungan pasien ke Poliklinik Hematologi RSUP Sangah Denpasar.

Metode: Penelitian ini merupakan suatu penelitian observasional pada pasien anemia yang datang ke poliklinik hematologi RSUP Sanglah dari April 2015-April 2017.

Kata kunci: Anemia, pola kunjungan pasien, poliklinik hematologi Cite Pasal Ini: Sintya, D.N.M.A., Adnyana, I.W.L., Aryana, I.G.P.S. 2020. Pola pasien anemia yang berkunjung ke Poliklinik Hematologi RSUP Sanglah dari April 2015-April 2017. Intisari Sains Medis 11(2): 851-855. D0I: 10.15562/ism.v11i2.207

\section{PENDAHULUAN}

Anemia merupakan masalah kesehatan yang memengaruhi masyarakat di seluruh dunia baik pada negara maju maupun negara berkembang. ${ }^{1}$ Dampak dari Anemia dapat ditemukan pada berbagai kalangan masyarakat baik di pedesaan
Hasil: Berdasarkan penelitian ini dapat dikonklusikan bahwa proporsi tertinggi pasien anemia yang datang ke Poliklinik Hematologi RSUP Sanglah paling banyak adalah dari kelompok umur 15-19 tahun. Sementara itu, berdasarkan kelompok jenis kelamin ditemukan bahwa presentasi pasien anemia perempuan adalah 55,8\% dengan 2,9\% dari pasien tersebut sedang dalam keadaan hamil sementara pasien anemia laki-laki adalah 44,2\%.

Simpulan: Dilihat dari penyebabnya pasien anemia yang datang ke Poliklinik Hematologi RSUP Sanglah dari April 2015-April 2017 paling banyak didiagnosis dengan tipe tidak terspesifikasi dengan $58,7 \%$ pasien anemia datang tanpa disertai penyakit lain dan 41,3\% datang dengan penyakit penyerta. maupun di perkotaan dan tidak terbatas pada salah satu jenis kelamin maupun kelompok umur. ${ }^{2}$

Anemia merupakan kondisi klinis yang bersifat multifaktorial dan dalam penangannya dibutuhkan pengetahuan mengenai penyebabnya. ${ }^{3}$ Penyebab
Ni Made Ayu Sintya D, Program Studi Pendidikan Dokter, Fakultas Kedokteran Universitas Udayana madeayusintya@gmail.com

Diterima: 06-04-2018

Disetujui: 15-06-2018

Diterbitkan: 01-08-2020 
yang paling umum adalah permasalahan nutrisi seperti kekurangan zat besi, folat, vitamin B12 dan protein. Selain itu juga ada gangguan lain seperti masalah kongenital dan penyakit-penyakit lainnya. ${ }^{1,4}$

Berdasarkan WHO, dikatakan bahwa satu dari empat orang didunia mengalami anemia dengan negara-negara di Asia Tenggara dikatakan memiliki risiko yang paling tinggi dan juga dikatakan memiliki beban anemia yang paling tinggi. ${ }^{5}$

Sebelum membahas lebih lanjut mengenai anemia, ada baiknya untuk terlebih dahulu membahas apa itu anemia. Anemia dapat didefinisikan sebagai keadaan dimana massa eritrosir dan/atau hemoglobin yang beredar tidak mampu untuk memenuhi fungsinya dalam menyediakan oksigen untuk jaringan tubuh. ${ }^{4}$ Terdapat definisi yang cukup luas mengenai anemia.

Jika mengutip dari pernyataan yang dikeluarkan oleh WHO, maka seorang pasien dapat dikatakan mengidap anemia jika memiliki kadar hemoglobin dibawah $120 \mathrm{~g} / \mathrm{L}$ untuk wanita dan $130 \mathrm{~g} / \mathrm{L}$ untuk laki-laki. ${ }^{5,6}$

Anemia itu sendiri dapat dikelompokan dengan berbagai cara. Dua pengelompokan anemia yang sering digunakan adalah klasifikasi anemia berdasarkan morfologi dan klasifikasi anemia berdasarkan penyebab terjadinya. Pengelompokan ini juga penting untuk menentukan pilihan pengobatan. ${ }^{7}$

Berdasarkan morfologi anemia dapat dikelompokkan berdasarkan nilai dari MCV (Mean Corpuscular Volume) menjadi anemia mikrositer $(\mathrm{MCV}<80 \mathrm{fl})$, anemia makrositer $(\mathrm{MCV}>98 \mathrm{fl})$ dan anemia normositer $(80 \mathrm{fl}<\mathrm{MCV}>98 \mathrm{fl}) .{ }^{8}$

Sementara itu, jika dilihat berdasarkan penyebabnya maka anemia dapat dibagi mejadi tiga kelompok besar yaitu anemia yang berhubungan dengan nutrisi, anemia hemolisis dan anemia aplastik lainnya. Anemia akibat kekurangan nutrisi dapat dibagi lebih lanjut menjadi anemia defisiensi besi, anemia defisiensi vitamin B12, anemia defisiensi folat dan anemia lainnya yang berhubungan dengan nutrisi. Anemia hemolisis juga dapat dibagi lebih lanjut menjadi anemia akibat gangguan enzyme, thalassemia dan anemia bulan sabit (Sickle-cell disordes) dan anemia hemolisis didapat. Sementara itu anemia aplastik lainnya dapat dibagi menjadi anemia sel darah merah murni diapat (erythroblastopenia), anemia aplastik lainnya, anemia akut posthemorrhagic, anemia pada penyakit kronis diklasifikasikan di kelompok penyakit lain dan anemia lainnya. ${ }^{9,10}$

Penyebaran anemia sangatlah luas, berdasarkan data dari WHO mengenai prevalensi anemia di seluruh dunia tahun 1993-2005 dikatakan bahwa secara global anemia diderita oleh 1.62 miliar atau $24.8 \%$ populasi dunia. Berdasarkan data yang sama diketahui bahwa prevalensi tertinggi anemia diderita oleh anak usia belum sekolah yaitu dibawah lima tahun.

Penelitian lain oleh Global Burden of Diseases 2010 menegaskan tingginya tingkat kejadian anemia di Asia Tenggara dengan tingkat prevalensi anemia 37,5\%. ${ }^{1}$ Berdasarkan penelitian tersebut juga ditemukan bahwa penyebab tersering yg ditemukan adalah anemia defisiensi besi. ${ }^{11}$

Sementara itu di Indonesia, Riskesdas atau Riset Kesehatan Dasar tahun 2013 yang dilakukan oleh Badan Penelitian dan Pengembangan Kesehatan Kementrian Kesehatan RI menyatakan bahwa berdasarkan kelompok umur presenase anemia yang paling tinggi adalah usia lanjut (di atas 75 tahun). ${ }^{2,12}$

\section{METODE PENELITIAN}

Penelitian ini merupakan penelitian analitik observasional dengan rancangan penelitian rekam medis pasien anemia yang datang ke poliklinik hematologi RSUP Sanglah Denpasar. Sampel penelitian ini adalah pasien yang terdaftar sebagai pasien anemia di poliklinik hematologi RSUP Sanglah dari April 2015-April 2017. Penelitian ini menggunakan rekam medis pasien anemia yang datang ke poliklinik hematologi RSUP Sanglah. Prosedur penelitian ini adalah pengambilan data melalui rekam medis pasien anemia yang datang ke poliklinik hematologi RSUP Sanglah dan diikuti dengan pengolahan data. Data yang telah didapatkan kemudian diolah dengan tahapan coding data, entry data, cleaning data, serta analisis data dengan menggunakan program IBM SPSS.

\section{HASIL}

Dari penelitian ini ditemukan bahwa dari total keseluruhan pasien yang memenuhi kriteria inklusi dan eksklusi dari bulan April 2015 hingga April 2017 didapatkan 1655 kunjungan pasien anemia ke Poliklinik Hematologi RSUP Sanglah. Dari keseluruhan kunjungan tersebut tercatat pasien yang telah terdiagnosis anemia sebanyak 608 orang yang datang dengan kunjungan berulang.

Dapat dilihat bahwa karakteristik pasien anemia di Poliklinik Hematologi RSUP Sanglah berdasarkan jenis kelamin adalah sebanyak $44,2 \%$ pasien berjenis kelamin laki-laki dan sebanyak 55,8\% merupakan perempuan. Selain dari segi perbedaan jenis kelamin, karakteristik pasien anemia juga dapat dilihat dari segi perbedaan usia. 
Tabel 1 Perbandingan jenis kelamin pada pasien anemia

\begin{tabular}{lcc}
\hline Jenis Kelamin & Frekuensi & Persentase (\%) \\
\hline Laki-laki & 269 & 44,2 \\
Perempuan & 339 & 55,8 \\
Total & 608 & 100 \\
\hline
\end{tabular}

\section{Tabel 2 Penyebaran usia pada pasien anemia}

\begin{tabular}{lcc}
\hline Usia & Frekuensi & Persentase (\%) \\
\hline 0 - 1 tahun & 26 & 4,3 \\
1 - 6 tahun & 58 & 9,5 \\
7 - 14 tahun & 69 & 11,3 \\
$15-59$ tahun & 342 & 56,3 \\
$>60$ tahun & 113 & 18,6 \\
Total & 608 & 100 \\
\hline
\end{tabular}

Tabel 3 Penyebaran klasifikasi anemia berdasarkan penyebab

\begin{tabular}{lcc}
\hline & F* $^{*}$ & (\%)** \\
\hline Anemia Defisiensi Besi & 20 & 3,3 \\
Anemia Defisiensi Vitamin B12 & 0 & 0 \\
Anemia Defisiensi Folat & 45 & 7,4 \\
Anemia Lainnya yang Berhubungan dengan Nutrisi & 1 & 0,1 \\
Anemia Akibat Gangguan Enzyme & 0 & 0 \\
Thalassemia & 49 & 8,1 \\
Anemia Bulan Sabit & 0 & 0 \\
Anemia Hemolisis Didapat & 2 & 0,3 \\
Aplasia Sel Darah Merah Murni Didapat & 0 & 0 \\
Anemia Aplastik Lainnya & 141 & 23,2 \\
Anemia Akut Posthemorrhagik & 10 & 1,6 \\
Anemia Karena Penyakit Kronik Diklasifikasikan di & 0 & 0 \\
Kelompok Penyakit Lain & & \\
Anemia Lainnya & 306 & 50,4 \\
Pasien Terdiagnosis Lebih Dari Satu Tipe Anemia & 34 & 5,6 \\
Total & 608 & 100 \\
\hline$*$ Fe & &
\end{tabular}

${ }^{*} \mathrm{~F}=$ Frekuensi

$* * \%=$ persentase

Tabel 4 Perbandingan antar pasien anemia yang didiagnosis dengan penyakit penyerta dan tanpa penyakit penyerta

\begin{tabular}{lcc}
\hline & Frekuensi & Persentase (\%) \\
\hline Dengan Penyakit Peserta & 251 & 41,3 \\
Tanpa Penyakit Peserta & 357 & 58,7 \\
Total & 608 & 100 \\
\hline
\end{tabular}

Berdasarkan data pada Tabel tersebut dapat dilihat bahwa persentasi anemia pada bayi usia 0-1 tahun adalah $4,3 \%$, pada anak usia satu sampai enam tahun adalah 9,5\%, anak usia 7-14 tahun adalah $11,3 \%$, dewasa usia dibawah 60 tahun adalah $56,3 \%$ dan usia lanjut di atas 60 tahun adalah 18,6\%.

Jika dilihat berdasarkan penyebaran klasifikasi anemia berdasarkan penyebabnya dapat ditemukan data seperti yang dijabarkan pada tabel 3 .

Berdasarkan tabel 3 ditemukan bahwa penyebab anemia pada pasien yang datang ke Poliklinik Hematologi RSUP Sanglah dari yang paling tinggi adalah anemia lainnya sebanyak 50,4\% diikuti dengan anemia aplastik lainnya $(23,2 \%)$, thalassemia $(8,1 \%)$, anemia defisiensi folat $(7,4 \%)$, anemia defisiensi besi $(3,3 \%)$, anemia akut posthemorrhagik $(1,6 \%)$, anemia hemolisis didapat $(0,3 \%)$ dan anemia lainnya yang berhubungan dengan nutrisi $(0,1 \%)$. Karakteristik lain yang ditemukan adalah perbandingan pasien datang dengan penyakit penyerta dan pasien yang datang tanpa penyakit penyerta yang tertera pada Tabel 4 .

Pasien anemia yang didiagnosis bersamaan dengan penyakit lain memiliki berbagai diagnosis yang berbeda. Adapun diagnosis tersebut dapat dilihat pada tabel 4. Berdasarkan data tersebut anemia yang paling banyak ditemukan adalah ketika pasien melakukan peninjauan kembali setelah selesainya pengobatan kondisi non malignansi (57,3\%) diikuti oleh penyebab lainnya (22,7\%), malignansi $(9,9 \%)$, neutropenia (4,7\%), gangguan lainnya pada cairan, elektrolit dan keseimbangan asam $(3,5 \%)$, leukemia $(2,7 \%)$, purpura dan kondisi hemorhajik lainnya $(2,7 \%)$, gangguan cardiovascular $(1,9 \%)$, kelainan ginjal $(1,9 \%)$, gangguan herediter $(1,5 \%)$ dan kelainan paru (1,5\%).

\section{DISKUSI}

Berdasarkan data yang dikeluarkan dari WHO mengenai pasien anemia pada tahun 1993-2005 diketahui bahwa anemia diderita oleh 1,62 miliar populasi di dunia atau $24,8 \%$ dari total populasi dunia dan data tersebut dikatakan bahwa prevalensi anemia paling tinggi pada anak usia belum sekolah. Sementara itu berdasarkan data yang diterbitkan oleh Riskesdas pada tahun 2013 mengenai pasien anemia di Indonesia dikatakan bahwa prevalensi penderita anemia di Indonesia yang paling tinggi adalah pada usia lanjut dengan persentase $46 \%$ dan paling rendah pada usia 25-34 tahun dengan persenase $16,9 \%$. Berdasarkan data yang sama yang telah dikeluarkan oleh Riskesdas mengenai penderita di provinsi Bali, prevalensi anemia pada anak usia dibawah 15 tahun ialah $9,8 \%$, pada wanita $19,7 \%$ dan pada laki-laki $13,1 \%$. Sedangkan berdasarkan penelitian ini ditemukan bahwa prevalensi anemia paling tinggi terdapat pada dewasa usia 15-59 tahun dan paling sedikit pada usia 0-1 tahun dengan persentase $4,3 \%$. 
Tabel 5 Penyebaran temuan penyerta pada pasien ketika didiagnosis dengan anemia

\begin{tabular}{lcc}
\hline Temuan Penyerta & F* & \%** \\
\hline Ditemukan ketika peninjauan kembali setelah & 144 & 57,3 \\
selesainya pengobatan kondisi non-malignansi & 25 & 9,9 \\
Malignansi & 7 & 2,7 \\
Leukemia & 7 & 2,7 \\
Purpura dan kondisi hemorrhajik lainnya & 12 & 4,7 \\
Neutropenia & 9 & 3,5 \\
Gangguan Lainnya pada Cairan, Elektrolit dan & 2 & 0,7 \\
Keseimbangan Asam & 4 & 1,5 \\
Penyakit Infeksi & 3 & 1,1 \\
Gangguan Herediter & 5 & 1,9 \\
Diabetes Mellitus & 4 & 1,5 \\
Gangguan Cardiovascular & 5 & 1,9 \\
Kelainan Paru & 57 & 22,7 \\
Kelainan Ginjal & 251 & 100 \\
Penyebab Lainnya & & \\
Total & & \\
\hline
\end{tabular}

${ }^{*} \mathrm{~F}=$ Frekuensi

${ }^{* * \%=}=$ persentase
Perbedaan angka tersebut dapat disebabkan oleh beberapa hal. Yang pertama adalah luasnya cakupan populasi yang diteliti. Data yang dikeluarkan oleh WHO merupakan hasil dari pendataan internasional yang mencakup pasien anemia dari seluruh dunia sementara data yang diterbitkan oleh Riskesdas mencakup seluruh penduduk Indonesia yang menderita anemia sementara penelitian ini mencakup seluruh pasien anemia yang datang ke Poliklinik Hematologi RSUP Sanglah Denpasar. Penyebab perbedaan yang kedua adalah lamanya penelitian dimana penelitian oleh WHO dilakukan dari tahun 1993 sampai tahun 2005 sementara pendataan Riskesdas dilakukan selama satu tahun dan penelitian ini dilakukan selama dua tahun.

\section{SIMPULAN}

Berdasarkan penelitian ini dapat disimpulkan bahwa total kunjungan pasien anemia di poliklinik hematologi RSUP Sanglah periode April 2015 sampai April 2017 adalah 1655 kunjungan dengan total penderita anemia sebanyak 608 pasien. Dari 608 pasien tersebut kelompok pasien anemia dengan proporsi paling tinggi yang datang ke Poliklinik Hematologi RSUP Sanglah adalah pasien dewasa kelompok usia 15-59 tahun dan yang paling rendah adalah bayi usia dibawah 1 tahun dengan persentase 4,3\%. Proporsi pasien laki-laki dan perempuan penderita anemia yang datang ke Poliklinik Hematologi RSUP Sanglah $44,2 \%$ untuk laki-laki dan 55,8\% untuk perempuan dimana $2.9 \%$ dari pasien perempuan tersebut sedang dalam keadaan hamil. Dari seluruh pasien anemia ditemukan bahwa sebanyak $58,7 \%$ pasien anemia datang tanpa adanya gangguan penyerta lain sementara $41,3 \%$ lainnya datang dengan disertai penyakit tertentu dimana anemia paling banyak ditemukan pada peninjauan ulang pasien setelah selesai pengobatan kondisi non-malignansi.

\section{UCAPAN TERIMA KASIH}

Pada kesempatan ini perkenankanlah penulis mengucapkan terima kasih yang sebesar-besarnya kepada dr. Suryadharma, SpPD-KGEH telah memberikan masukan dan arahan dalam proses pengerjaannya.

\section{DAFTAR PUSTAKA}

1. Kassebaum NJ, Jasrasaria R, Naghavi M, dkk. Plenary Paper Red Cells, Iron, And Erythropoiesis A systematic analysis of global anemia burden from 1990 to 2010. 2015; 615-625.

2. Departemen Kesehatan RI. Riset Kesehatan Dasar 2013. Jakarta: Departemen Kesehatan RI; 2014. 
3. Maakaron AJE, Editor C, Besa EC. Anemia. 2015; 1-6.

4. Dowling TC. Prevalence, etiology, and consequences of anemia and clinical and economic benefits of anemia correction in patients with chronic kidney disease: An overview; 2007: 53-37.

5. WHO. Worldwide prevalence of anaemia; 2005. Tersedia pada: http://whqlibdoc.who.int/publications/ 2008/9789241596657 eng.pdf?ua=1.

6. Tettamanti M, Lucca U, Gandini F, et al. Prevalence, incidence and types of mild anemia in the elderly: the "Health and Anemia" population-based study. Haematologica. 2010; 95(11):1849-1856.

7. Moreno Chulilla JA. Classification of anemia for gastroenterologists. World J Gastroenterol. 2009; 15(37):4627.

8. Donker AE, Raymakers RAP, Vlasveld LT, et al. CME Article Practice guidelines for the diagnosis and management of microcytic anemias due to genetic disorders of iron metabolism or heme synthesis; 2015.

9. DeLoughery TG. Microcytic anemia. $N$ Engl J Med. 2014; 1324-1331.
10. Bakta, I Made. 2014. Hematologi Klinik Ringkas cetakan 2014. Penerbit Buku Kedokteran EGC. Jakarta: EGC.

11. Longo DL, Camaschella C. Iron-Deficiency Anemia. N Engl J Med. 2015; 1832-1843.

12. Widyaningrum, Destiana. Studi Ekologi Hubungan Prevalensi Malaria, Konsumsi Makanan, dan Kemiskinan dengan Prevalensi Anemia Pada Penduduk di Wilayah Perkotaan Indonesia Tahun 2007 (Analisis Data RISKESDAS dan SUSENAS 2007). FKM Universitas Indonesia. Depok: Universitas Indonesia; 2012.

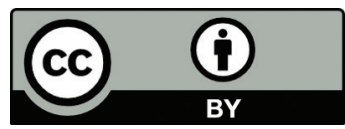

This work is licensed under a Creative Commons Attribution 